\title{
Improved Anti-tumor Activity and Safety of Interleukin-13 Receptor Targeted Cytotoxin by Systemic Continuous Administration in Head and Neck Cancer Xenograft Model
}

\author{
Koji Kawakami, Syed R. Husain, Mariko Kawakami, and Raj K. Puri \\ Laboratory of Molecular Tumor Biology, Division of Cellular and Gene Therapies, Center for Biologics \\ Evaluation and Research, Food and Drug Administration, Bethesda, MD, USA \\ Accepted June 26, 2002
}

\begin{abstract}
Background: IL-13 receptor (IL-13R) targeted cytotoxin, IL13-PE38QQR, has been shown to have very potent anti-tumor activity to IL-13R-expressing head and neck tumor cells in vitro and in vivo. However, its effect is limited in aggressive tumors. To further improve the anti-tumor activity and safety of IL-13 cytotoxin, we employed continuous infusion technique in animal model of head and neck cancer.

Materials and Methods: We surgically implanted continuous infusion (CI) pump intraperitoneally that released drug for 7 days, and its anti-tumor effect was evaluated. A comparison was made for antitumor activity and safety with intravenously (IV) administered IL-13 cytotoxin in a head and neck (KCCT873 and HN12) subcutaneous (SC) xenograft tumor models in nude mice. Vital organ
\end{abstract}

toxicities were assessed by histologic examinations and blood serum chemistry analyses.

Results: The 50 or $75 \mu \mathrm{g} / \mathrm{kg} /$ day for 7 days of IL-13 cytotoxin either by IV or CI administration did not show any difference in safety or anti-tumor activity. IV administration of 150 or $200 \mu \mathrm{g} / \mathrm{kg} /$ day of IL-13 cytotoxin for 7 days was lethal to nude mice, whereas $200 \mu \mathrm{g} / \mathrm{kg} /$ day $X$ 7 days of CI administration was highly effective in the regression of established tumors without any toxicities. Additionally, CI administration of IL-13 cytotoxin (200 $\mu \mathrm{g} / \mathrm{kg} /$ day) showed growth inhibition of larger HN12 tumors in nude mice.

Conclusion: With a CI schedule, IL-13 cytotoxin can be systemically administrated at approximately twice the dose otherwise given by daily IV bolus administration.

\section{Introduction}

Desirable anti-tumor activities and unexpected toxicities of novel anti-tumor agents depend partly on drug delivery routes. Even a potentially powerful anti-tumor agent can cause unexpected serious adverse events or organ toxicities by a certain route of drug administration. To resolve these problems, therapeutic approaches such as prolonged drug release mechanisms or continuous infusion of drug have been reported to increase drug efficacy (1-4). Because of shorter half-lives of drugs, intravenous (IV) or intraperitoneal (IP) administration limits their efficacy. Moreover, multiple bolus administrations increase the susceptibility to organ toxicities. Therefore, continuous infusion (CI) of drugs can be an ideal way of systemic administration of novel cancer therapeutics.

Interleukin-13 (IL-13) is a helper T cell type 2 (Th2)-derived pleiotropic immune regulatory cytokine (5). It has predominant biological activities on B cells, monocytes, fibroblasts, and endothelial cells

Address correspondence to: R.K. Puri, Laboratory of Molecular Tumor Biology, Division of Cellular and Gene Therapies, Center for Biologics Evaluation and Research, Food and Drug Administration, NIH Building 29B, Room 2NN10, 29 Lincoln Drive MSC 4555, Bethesda, MD 20892. Phone: 301-827-0471; fax: 301-827-0449; e-mail: puri@cber.fda.gov. and plays a major role in inflammatory diseases. IL-13 may also play a prominent role in cancer because receptors for this cytokine are overexpressed. IL-13 is also an autocrine growth factor for some cancer cells (6). We first identified plasma membrane receptors for IL-13 on several human renal cell carcinoma cell lines $(7,8)$, and since then we reported that a variety of human solid cancer cell lines including AIDS-associated Kaposi's sarcoma $(9,10)$, glioblastoma $(11,12)$, prostate cancer (13), ovarian carcinoma (14), and head and neck cancer (SCCHN) (15-17) express receptor for IL-13 (IL-13R). In recent years, the receptors for IL-13R have been extensively characterized. We have demonstrated that IL-13R may exist as three different forms in different cell types $(7,14,18-21)$. Two different chains of the IL-13R, IL-13R $\alpha 1$ (also known as IL-13R $\alpha^{\prime}$ ) and IL-13R $\alpha 2$ (also known as IL-13R $\alpha$ ) have been cloned. The murine and human IL-13R $\alpha$ l chain was cloned first (22-24). This chain binds IL-13 with low affinity but when coupled with IL-4R $\alpha$ chain (also known as IL-4R $\beta$ ) binds IL-13 with high affinity and mediates IL-13-induced signaling $(14,19,20,23,25)$. The second chain of IL-13R, IL-13R $\alpha 2$, was cloned from a human renal cell carcinoma cell line (Caki-1). This chain has $50 \%$ homology to IL-5R at the DNA level, has a short intracellular domain, and binds IL-13 with 
approximately 50-times higher affinity than IL-13R $\alpha 1$ chain $(26,27)$. More recently, we have reported that IL-13R $\alpha 2$ chain can play an important role in receptor binding and internalization $(28,29)$.

Based on our findings that many solid cancer cells express IL-13R, we produced IL-13 cytotoxin, termed IL13-PE38QQR, which is composed of IL-13 and a mutated form of a Pseudomonas exotoxin. IL13PE38QQR has a potent anti-tumor activity to IL-13R expressing tumor cells in vitro $(8,9,13,15,17,30,31)$ and in vivo $(10,16,32,33)$. Despite the success of preclinical animal studies, the effect of systemic injection of IL-13 cytotoxin has been limited in some of the most aggressively growing head and neck tumor xenograft models (16). To achieve the optimum effect of this targeted agent, a higher dose needs to be administrated. However, systemic bolus injection of higher doses caused organ toxicities as described previously $(10,33)$. The major organ damage caused by bacterial toxin is irreversible liver toxicity (34-36). To avoid liver toxicity, systemic drug exposure needs to be either of a lower dose or prolonged. Thus, we hypothesized that continuous release of IL- 13 cytotoxin in the systemic circulation would enhance its anti-tumor effect as well as reduce organ toxicities. Therefore, in this study we employed mini-osmotic pumps that can infuse drugs continuously and compared the anti-tumor activity and safety of IL-13 cytotoxin given by IV bolus injections and by $\mathrm{CI}$.

\section{Materials and Methods}

Recombinant Cytotoxin and Cell Lines

Recombinant IL13-PE38QQR was produced and purified in our laboratory $(17,30)$. The purified protein was found to have 3200 endotoxin EU/mg protein. The final concentration of endotoxin injected to animals ranged between 3.2 and $4.8 \mathrm{EU} /$ dose. The range of endotoxin is lower than the allowable limit in the clinic. Human head and neck cancer cell line WSU-HN12 (termed HN12) was a kind gift from Dr. Andrew Yeudall (National Dental and Craniofacial Research Institute, NIH, Bethesda, MD, USA) (37). KCCT873 cell line was established at Research Institute, Kanagawa Cancer Center (Yokohama, Japan) (38). Cells were cultured in Eagle's Modified Essential Medium (HN12) or RPMI 1640 (KCCT873) containing $10 \%$ fetal bovine serum (Biowhittaker Inc., Walkersville, MD, USA), 1 mM HEPES, $1 \mathrm{mM}$ L-glutamine, $100 \mu \mathrm{g} / \mathrm{ml}$ penicillin, and $100 \mu \mathrm{g} / \mathrm{ml}$ streptomycin (Biowhittaker).

\section{Animal Studies}

Athymic nude mice 4 weeks old (about $20 \mathrm{~g}$ in body weight) were obtained from the Frederick Cancer Center Animal Facilities (National Cancer Institute, Frederick, MD, USA). Animal care was taken in accordance with the guidelines of the NIH Animal Research Advisory Committee. Human head and neck tumor xenografts were established in the nude mice by subcutaneous (SC) injection of cells into the flank. HN 12 or KCCT873 cells $\left(5 \times 10^{6}\right)$ were injected in $150 \mu \mathrm{l}$ of PBS. Palpable tumors developed within 3-4 days. The mice then received injections of excipient $(0.2 \%$ HSA in PBS) or chimeric toxin either IV (150 $\mu \mathrm{l}$ using a 27-gauge needle through the tail vein) or CI $(0.5 \mu \mathrm{l} / \mathrm{hr}$ for 7 days). Continuous administration was performed by loading a miniosmotic Alzet pump (Alza, Palo Alto, CA, USA) with $100 \mu \mathrm{l}$ IL- 13 cytotoxin. The pump was surgically implanted IP on day 4 after tumor implantation. In brief, nude mice were anesthetized with ketamine and xylazine and placed in the supine position. An upper midline abdominal incision was made, and pumps were inserted from the top of the device.

\section{Statistical Analysis}

Two perpendicular diameters of tumors were carefully measured by a Vernier caliper and tumor size was then calculated by multiplying the length and width of the tumor on a given day. The statistical significance of tumor regression was calculated by Student's $t$ test.

\section{Histologic Analysis}

Organs from the experimental animals were fixed in $10 \%$ formalin and $5-\mu \mathrm{m}$ tissue sections were prepared, and stained with hematoxylin and eosin.

\section{Results}

A Better Anti-tumor Activity of IL13-PE38QQR

by CI Compared with IV Administration

in KCCT873 Tumor Xenografts

To compare the anti-tumor activity of IL-13 cytotoxin via IV administration and CI, 50 or $75 \mu \mathrm{g} / \mathrm{kg} /$ day of IL-13 cytotoxin was injected IV (one injection per day for 7 days) or mini osmotic pumps (350 or $525 \mu \mathrm{g} / \mathrm{kg}$ total infusion for 7 days) were surgically implanted IP on day 4 in KCCT873 tumor xenografts. As shown in Figure 1 (A and B), KCCT873 tumors without treatment (excipient control) grew well and mean tumor size became $162-190 \mathrm{~mm}^{2}$ by day 31 . On the other hand, tumors in the treated mice began regressing during the treatment period; however, when the treatment period was over, all the tumors began growing gradually. Although in mice treated with $50 \mu \mathrm{g} / \mathrm{kg} /$ day of IL- 13 cytotoxin by both routes showed significant regression of tumor in size $\left(79 \mathrm{~mm}^{2}\right.$ in IV and $66 \mathrm{~mm}^{2}$ in CI tumors) by day 31 ( $p<0.008$ compared to control), there was no significant difference $(p=0.14)$ in the anti-tumor effect between IV and CI drug administration groups.

In mice treated with $75 \mu \mathrm{g} / \mathrm{kg} / \mathrm{day}$ of IL- 13 cytotoxin (Fig. 1B), all tumors began to grow slowly after the treatment period. However, the antitumor activity of IL- 13 cytotoxin by CI was slightly better compared with IV administration, although the difference was not statistically significant. Mice 


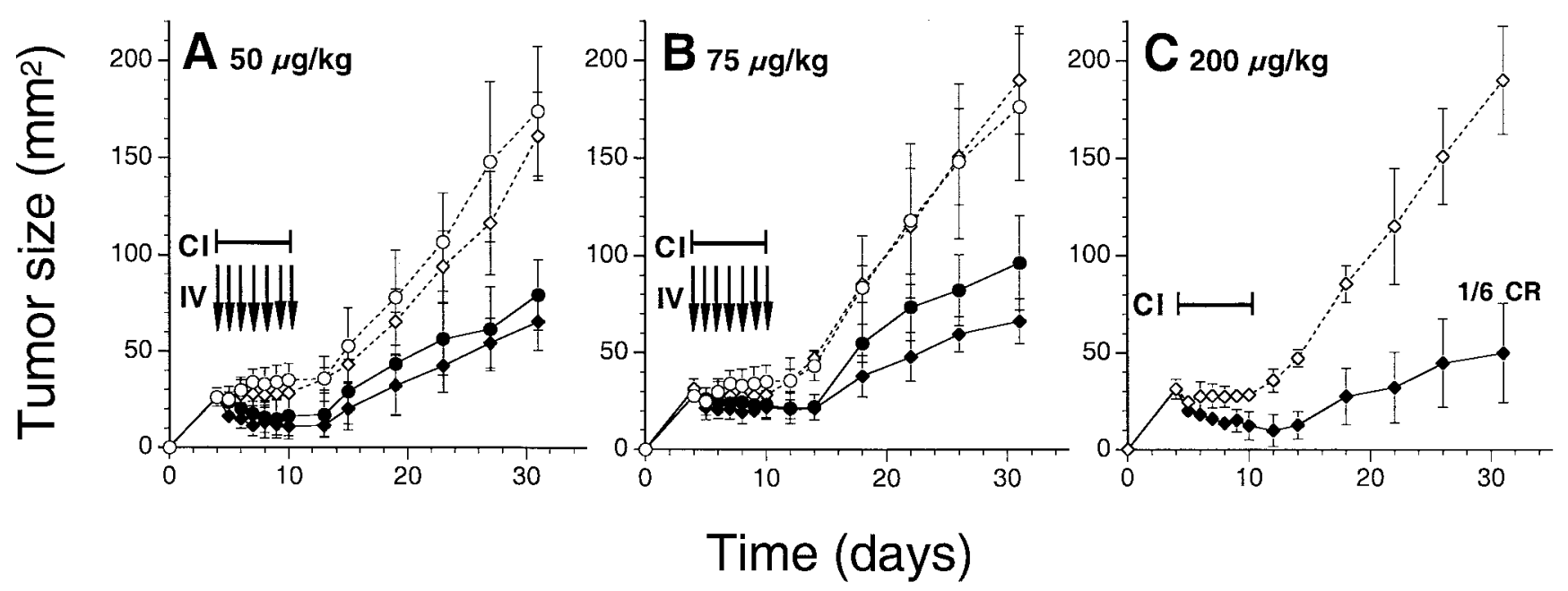

\begin{tabular}{|llll|}
\hline$\cdots-\cdots$ & IV Control (excipient only) $-\bullet$ & IV $75 \mu \mathrm{g} / \mathrm{kg}$ QDx7days \\
$\cdots-\cdots$ & Cl Control (excipient only) & - & Cl $75 \mu \mathrm{g} / \mathrm{kg}$ x7days \\
\hline
\end{tabular}

Fig. 1. Comparison of anti-tumor activity of IL-13 cytotoxin in KCCT873 tumor xenografted nude mice between IV and CI routes. Male mice bearing subcutaneous tumor were treated with $50 \mu \mathrm{g} / \mathrm{kg} / \mathrm{day}$ (A), $75 \mu \mathrm{g} / \mathrm{kg} / \mathrm{day}$ (B), or $200 \mu \mathrm{g} / \mathrm{kg} / \mathrm{day}$ (C) of IL13-PE38QQR by either IV or continuous infusion (CI) from day 4-10 (7 days). Abbreviations: CR, complete response. Experiments were performed twice with similar results.

were also given $200 \mu \mathrm{g} / \mathrm{kg} /$ day of IL-13 toxin by CI (total $1400 \mu \mathrm{g} / \mathrm{kg}$ during 7 days). Two out of six tumors completely disappeared by day 12. Although one tumor recurred, by day 31 one mouse remained tumor free and the mean size of tumors was significantly smaller $\left(50 \mathrm{~mm}^{2}\right)$ compared with tumors in mice with excipient control-loaded pump $\left(190 \mathrm{~mm}^{2}\right)$ $(p<0.001)$ (Fig. 1C).

\section{Evaluation of Systemic Administration} of IL13-PE38QQR in HN12 Tumor Xenografts

We next examined the maximum tolerable dose of IL-13 cytotoxin by systemic administration of the drug. Four days after the implantation of $\mathrm{HN} 12$ tumors in nude mice, animals were treated by either IV (150 or $200 \mu \mathrm{g} / \mathrm{kg} /$ day for 7 days; total 1050 or $1400 \mu \mathrm{g} / \mathrm{kg}$, respectively) or CI $(300 \mu \mathrm{g} / \mathrm{kg} /$ day for 7 days; total $2100 \mu \mathrm{g} / \mathrm{kg}$ ). As shown in Figure 2A, all the treated tumors started regressing as soon as the treatment began. However, in the $200 \mu \mathrm{g} / \mathrm{kg} /$ day IV treatment group $(n=4)$, all the mice died by day 11. In the $150 \mu \mathrm{g} / \mathrm{kg} /$ day IV treatment group $(n=8)$, seven out of eight mice died by day 12. The last mouse left was sick during the treatment period, but recovered later. The survival rate from toxicity in both IV treatment groups was poor $(12.5 \%$ in $150 \mu \mathrm{g} / \mathrm{kg}$ and $0 \%$ in $200 \mu \mathrm{g} / \mathrm{kg}$ ) (Fig. 2B).

In sharp contrast, all mice in the $300 \mu \mathrm{g} / \mathrm{kg} /$ day CI treatment group $(n=8)$ remained healthy throughout the experimental period. In two out of eight mice complete disappearance of tumors was observed by day 10 (Fig. 2A). Although tumors started to grow again, the mean size of the tumors on day 27 $\left(24 \mathrm{~mm}^{2}\right)$ was significantly smaller $(p<0.005)$ than the mean size of control tumors $\left(208 \mathrm{~mm}^{2}\right)$. The survival rate in this group was $100 \%$ compared to control group on day 30 (Fig. 2B).

To assess the organ toxicities after treatment with IL-13 cytotoxin by either IV or CI routes, blood serum chemistry and histologic analyses of vital organs were performed. Blood was drawn on day 11 ( 1 day after the completion of the treatment period) for serum chemistry. As shown in Table 1, after $150 \mu \mathrm{g} / \mathrm{kg} /$ day IV administration of IL-13 cytotoxin, blood serum potassium, CPK, LDH, and AST/ALT levels were greatly increased compared with blood samples from excipient only injected. Animals that received 200 or $300 \mu \mathrm{g} / \mathrm{kg} /$ day by CI also showed elevations in CPK, $\mathrm{LDH}$, and AST/ALT; however, these increases were not as high as seen in IV treated mice.

Samples from vital organs such as kidney, liver, lung, and spleen were also harvested on day 10 or 11 and histology of the tissue sections was assessed. As summarized in Table 2, after 150 or $200 \mu \mathrm{g} / \mathrm{kg} /$ day for 7 days of IV administration of IL-13 cytotoxin, major histologic changes in vital organs were found. As expected, these histologic changes were more severe in the $200 \mu \mathrm{g} / \mathrm{kg} /$ day IV treated mice compared with the $150 \mu \mathrm{g} / \mathrm{kg} /$ day IV treated mice. Organ toxicities including notable liver necrosis, multifocal necrosis of kidney, and pulp degeneration of spleen were observed in $200 \mu \mathrm{g} / \mathrm{kg} /$ day for 7 days IV treated mice. Tissue sections from $100 \mu \mathrm{g} / \mathrm{kg} /$ day IV treated mice did not show significant histologic changes (data not shown). These histologic changes were considered to be signs of organ toxicities caused by IL-13 cytotoxin. 
A

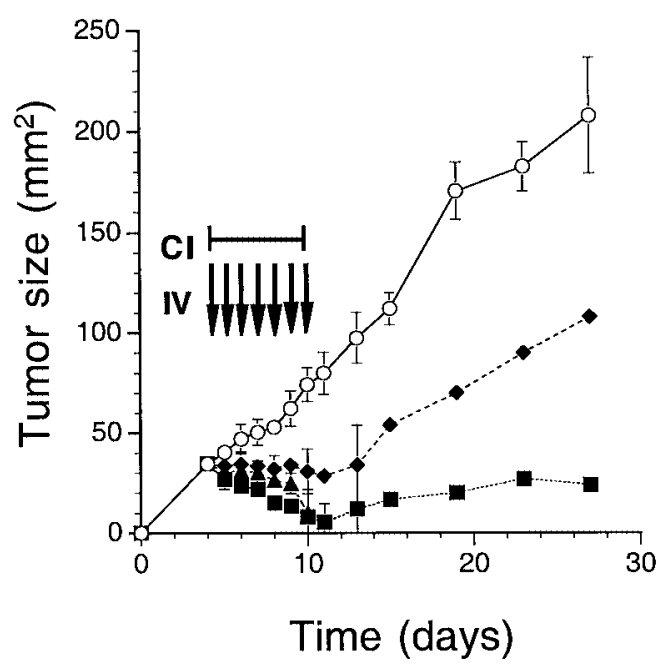

B

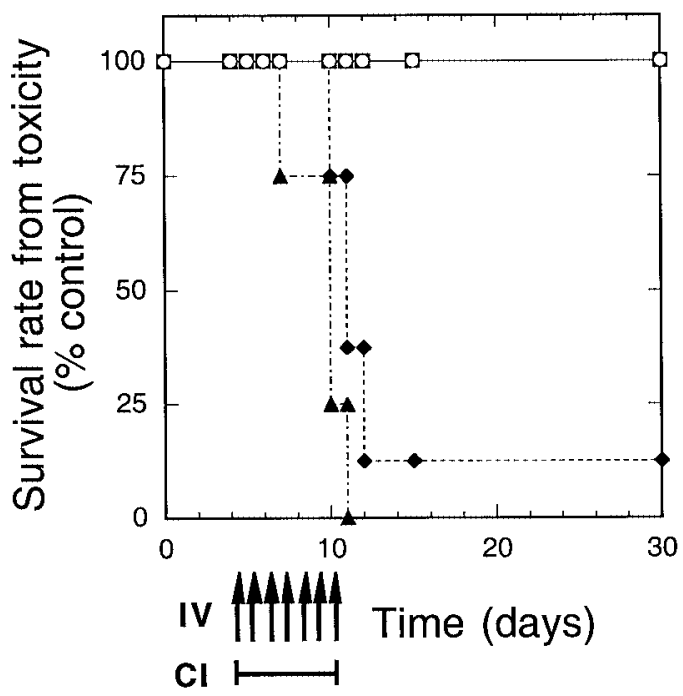

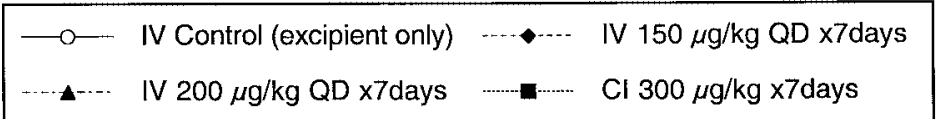

Fig. 2. Toxicity study in HN12 tumor xenografted nude mice. Male mice bearing subcutaneous tumors were treated with excipient only IV $(\mathrm{O} ; n=6), 150 \mu \mathrm{g} / \mathrm{kg} /$ day IV $(\diamond ; n=8), 200 \mu \mathrm{g} / \mathrm{kg} /$ day IV $(\boldsymbol{\Delta} ; n=4)$, or $300 \mu \mathrm{g} / \mathrm{kg} / \mathrm{day}$ CI $(\boldsymbol{\square} ; n=8)$ of IL13PE38QQR from day 4 to 10 (7 days). (A) Anti-tumor activity of IL-13 toxin is shown. Bars represent the SD. (B) survival rates are expressed as percentage of surviving mice compared with control. Experiments were performed twice with similar results.

On the other hand, the mice treated with 200 and $300 \mu \mathrm{g} / \mathrm{kg} /$ day of CI administration of IL-13 cytotoxin did not show severe histologic changes. Although slight abnormalities were found in liver and kidney samples from the $300 \mu \mathrm{g} / \mathrm{kg} /$ day CI treated mice, changes were apparently modest compared with $150 \mu \mathrm{g} / \mathrm{kg} /$ day IV treated mice. As shown in Figure 3, $200 \mu \mathrm{g} / \mathrm{kg}$ IV dose caused considerable histologic changes in vital organs. Considering $200 \mu \mathrm{g} / \mathrm{kg} /$ day dose delivered by either IV injections or CI were same in total dose $(1400 \mu \mathrm{g} / \mathrm{kg}$ for 7 days), these results suggest that CI route is definitely less toxic to vital organs than IV route.

Continuous Infusion Increased Anti-tumor Activity of IL13-PE38QQR in HN12 Tumor Xenografts

Our blood serum chemistry analysis and histologic examinations of vital organs suggested that $100 \mu \mathrm{g} / \mathrm{kg} /$ day (IV) or $200 \mu \mathrm{g} / \mathrm{kg} /$ day (CI) IL-13

Table 1. Changes in blood serum chemistry after the treatment with IL13-PE38QQR

\begin{tabular}{|c|c|c|c|c|c|c|}
\hline \multirow[b]{2}{*}{ Profile } & \multirow{2}{*}{$\begin{array}{c}\text { Reference Range } \\
\text { (Units) }\end{array}$} & \multicolumn{2}{|c|}{ Intravenous Administration } & \multicolumn{3}{|c|}{ Continuous Infusion } \\
\hline & & Control $^{*}$ & $150 \mu \mathrm{g} / \mathrm{kg}$ & Control & $200 \mu \mathrm{g} / \mathrm{kg}$ & $300 \mu \mathrm{g} / \mathrm{kg}$ \\
\hline Sodium & $150-162(\mathrm{mEq} / \mathrm{l})$ & 150 & 141 & 151 & 152 & 144 \\
\hline Potassium & $3.8-6.8(\mathrm{mEq} / \mathrm{l})$ & 6.0 & 20.1 & 5.7 & 5.8 & 16.3 \\
\hline $\mathrm{CPK}^{+}$ & $0-800(\mathrm{U} / \mathrm{l})$ & 179 & 14414 & 60 & 471 & 6665 \\
\hline $\mathrm{LDH}$ & $260-680(\mathrm{U} / \mathrm{l})$ & 1083 & 5032 & 663 & 1353 & 2490 \\
\hline AST (GOT) & $72-288(\mathrm{U} / \mathrm{l})$ & 208 & 1482 & 70 & 125 & 565 \\
\hline ALT (GPT) & 24-140 (U/l) & 76 & 723 & 28 & 88 & 91 \\
\hline Albumin & $2.6-4.6(\mathrm{~g} / \mathrm{dl})$ & 2.8 & 1.9 & 2.5 & 2.7 & 3.4 \\
\hline
\end{tabular}

* Data represent the mean of blood samples from two animals from each group.

+ CPK, creatinine phosphokinase. 
Table 2. Histologic changes in vital organs after the treatment with IL13-PE38QQR*

\begin{tabular}{|c|c|c|c|c|}
\hline & \multicolumn{2}{|c|}{ Intravenous Administration } & \multicolumn{2}{|c|}{ Continuous Infusion } \\
\hline & $150 \mu \mathrm{g} / \mathrm{kg}$ & $200 \mu \mathrm{g} / \mathrm{kg}$ & $200 \mu \mathrm{g} / \mathrm{kg}$ & $300 \mu \mathrm{g} / \mathrm{kg}$ \\
\hline Liver & $\begin{array}{l}\text { Mild multi-focal necrosis, } \\
\text { hydrophilic degeneration } \\
\text { of pericentral vein cells }\end{array}$ & $\begin{array}{l}\text { Atrophic change, } \\
\text { Severe multi-focal necrosis, } \\
\text { collapse of structure }\end{array}$ & NC & Mild cell degeneration \\
\hline Lung & $\mathrm{NC}^{\dagger}$ & Alveolar wall thickness & NC & NC \\
\hline Kidney & $\begin{array}{l}\text { Cell hypertrophy, mild } \\
\text { focal necrosis, basement } \\
\text { thickness }\end{array}$ & Multi-focal necrosis & NC & Cell hypertrophy \\
\hline Spleen & Fibrosis & Pulp degeneration & NC & $\mathrm{NC}$ \\
\hline
\end{tabular}

* Data represent common findings from two animals in each group.

${ }^{\dagger} \mathrm{NC}$, no remarkable change.

cytotoxin can be administrated systemically for 7 days without toxic side effects. To compare the anti-tumor effect of $100 \mu \mathrm{g} / \mathrm{kg} / \mathrm{day}$ (IV) or $200 \mu \mathrm{g} / \mathrm{kg} /$ day (CI), HN 12 cells were implanted SC into male or female nude mice. IL-13 cytotoxin was administrated for 7 days from day 4 to day 10. As shown in Figure 4A, tumors began regressing during IV treatment period in both male and female mice, and by day 10, tumors disappeared in one out of six mice in both male and female groups. Tumors started growing after the treatment period and by day 14 tumors recurred in all the mice. Although the mean size of tumors was significantly smaller (male, $71 \mathrm{~mm}^{2}$; female, $91 \mathrm{~mm}^{2}$ ) compared with excipient only injected control tumors (male, $184 \mathrm{~mm}^{2}$; female, $191 \mathrm{~mm}^{2}$ ) on the day of termination of the experiment (day 27; $p<0.0005$ ). No complete responders to IL-13 cytotoxin were observed. No significant difference was observed in the anti-tumor activity of IL-13 cytotoxin in either male or female mice.

As shown in Figure 4B, tumors in $200 \mu \mathrm{g} / \mathrm{kg} /$ day CI treatment group also regressed during treatment period in both male and female mice; however, the tumors regressed more quickly than the IV treatment group (100 $\mu \mathrm{g} / \mathrm{kg} /$ day; Fig. 4A). By day 11 , tumors completely disappeared in three out of six male mice and two out of six female mice. In the rest of mice, tumors began growing gradually after the drug infusion period; recurrence was observed in one each male and female mouse. Nevertheless, two of six male mice and one of six female mice remained tumor-free until termination of the experiment (day 27). The mean size of tumors in treated mice (male, $46 \mathrm{~mm}^{2}$; female, $72 \mathrm{~mm}^{2}$ ) were significantly
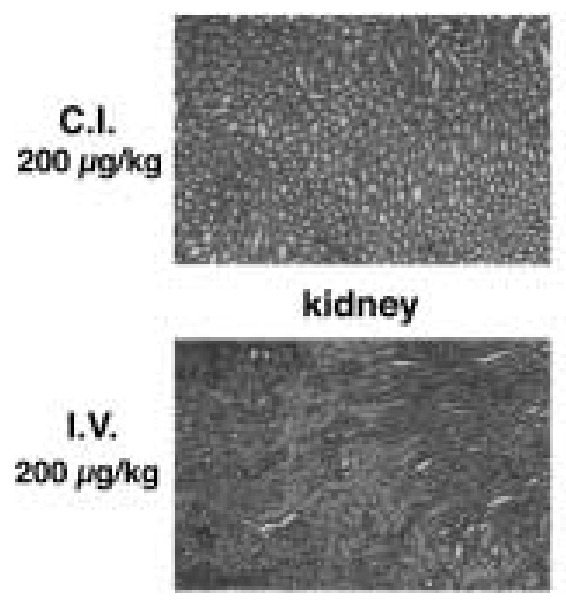

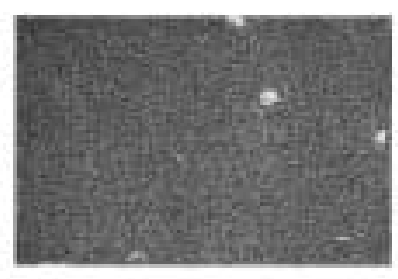

liver

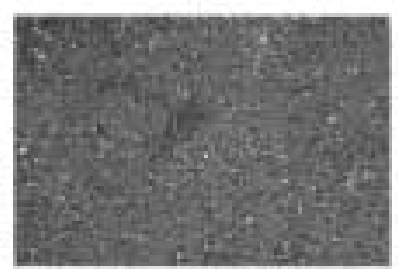

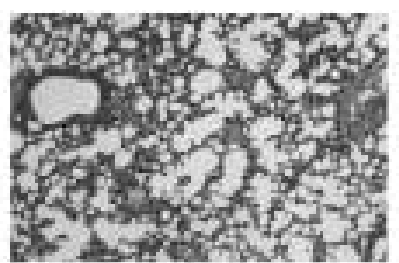

lung

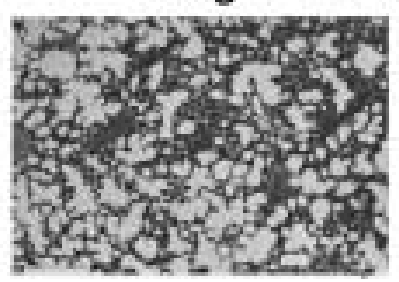

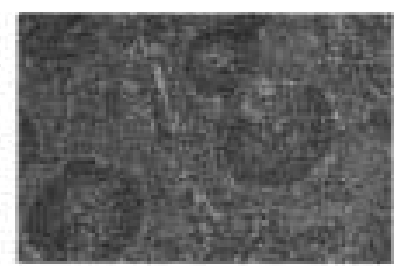

spleen

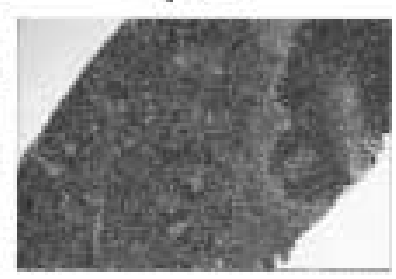

Fig. 3. Comparison of histologic changes after treatment with $200 \mu \mathrm{g} / \mathrm{kg} /$ day of IL-13 cytotoxin by IV or CI. Male mice bearing HN12 subcutaneous tumors were treated with $200 \mu \mathrm{g} / \mathrm{kg} /$ day of IL13-PE38QQR by either IV or CI from day 4 to day 10 (7 days). On day 11, organs were harvested for histologic examination. 

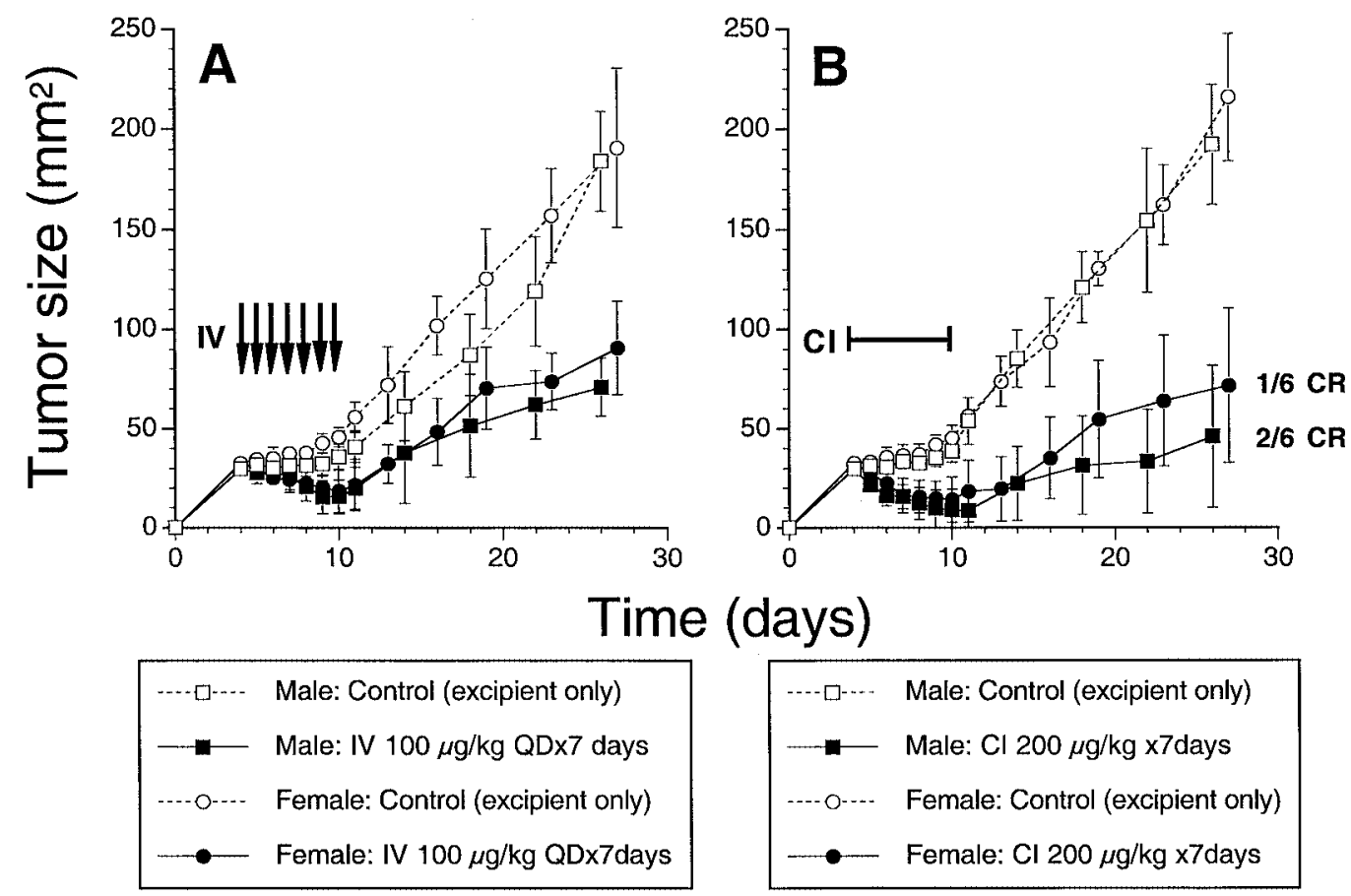

Fig. 4. Anti-tumor activity of IL-13 cytotoxin in HN12 tumor xenografted mice. Male and female mice bearing SC tumors were treated with $100 \mu \mathrm{g} / \mathrm{kg} /$ day IV (A) or $200 \mu \mathrm{g} / \mathrm{kg} /$ day CI (B) of IL13-PE38QQR from day 4 to day $10(7$ days) $(n=6)$. Bars represent the SD; CR, complete response.

smaller compared with control mice that were implanted with excipient only loaded CI pump (male, $192 \mathrm{~mm}^{2}$; female, $\left.216 \mathrm{~mm}^{2}\right)(p<0.0005)$. It appears that toxicity and anti-tumor activity of IL-13 cytotoxin was not gender specific (tumor regression, male $71 \%$ versus female $67 \%$ ).

\section{Anti-tumor Activity of IL13-PE38QQR in Large SCCHN Tumor Xenografts}

Finally, to assess the anti-tumor effect of IL-13 cytotoxin in large SCCHN tumor model, HN12 tumors were implanted SC in nude mice. When tumors grew to mean size of $87 \pm 12 \mathrm{~mm}^{2}$ (day 13), animals received IL-13 cytotoxin either by IV ( $100 \mu \mathrm{g} / \mathrm{kg} /$ day for 7 days) or CI $(200 \mu \mathrm{g} / \mathrm{kg} /$ day for 7 days) routes. Excipient only injected (IV) tumors grew rapidly, reaching $199 \mathrm{~mm}^{2}$ by the end of experiment (day 29) (Fig. 5). On the other hand, tumors treated with IL-13 cytotoxin showed growth inhibition during the treatment period by both IV and CI routes. No complete responders were generated; however, large size head and neck tumors were profoundly regressed. By day 29, mean tumor size in the IV group was $113 \mathrm{~mm}^{2}$ and CI group was $60 \mathrm{~mm}^{2}$, which were significantly smaller $(p<0.0005$ in both groups) when compared to control (mean tumor size $199 \mathrm{~mm}^{2}$ ). These data suggest that IL-13 cytotoxin mediates anti-tumor effects on large SCCHN tumors in a dose-dependent manner. The maximum tolerated dose by CI route was superior than maximum tolerated dose by IV route.

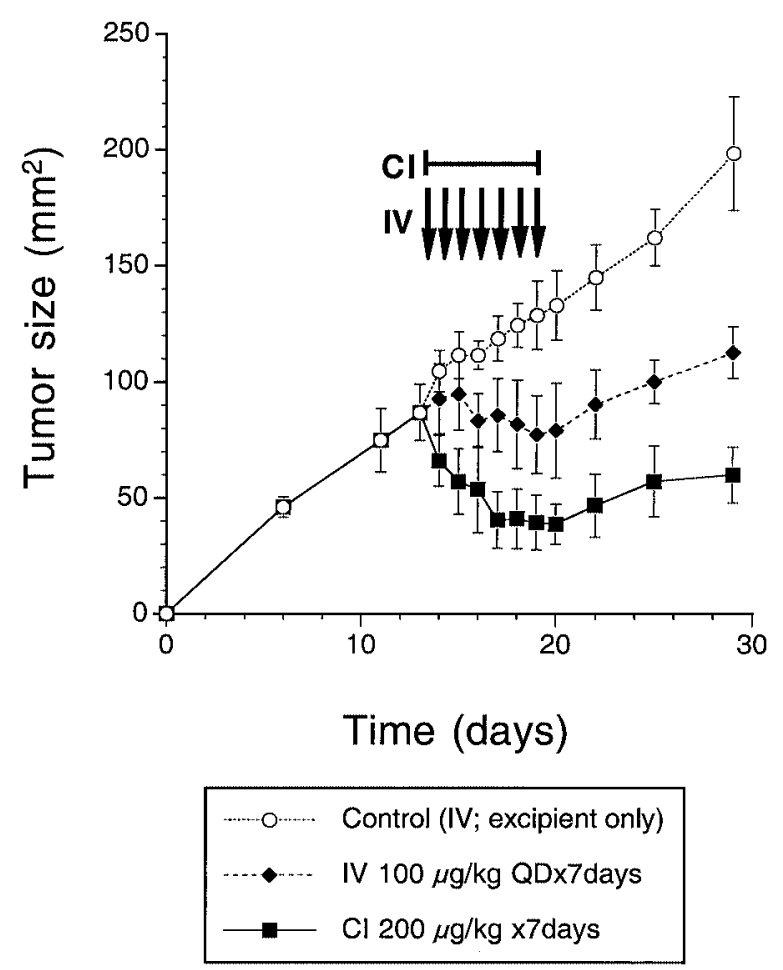

Fig. 5. Anti-tumor activity of IL-13 cytotoxin in large HN12 tumor models in mice. Male mice bearing SC large tumors (mean tumor size $87 \pm 12 \mathrm{~mm}^{2}$ ) were treated with $100 \mu \mathrm{g} / \mathrm{kg} / \mathrm{day}$ IV or $200 \mu \mathrm{g} / \mathrm{kg} /$ day CI of IL13-PE38QQR from day 13 to 19 (7 days); bars, SD $(n=7)$. 


\section{Discussion}

In this study, we demonstrated that systemic continuous administration decreases the toxic effects of IL-13 cytotoxin. When SC SCCHN tumor-bearing nude mice were treated with IL-13 cytotoxin by either IV or CI routes, the maximum tolerated dose by IV administration was found to be $100 \mu \mathrm{g} / \mathrm{kg} /$ day for 7 days, and $200 \mu \mathrm{g} / \mathrm{kg} /$ day for 7 days by CI route. Because CI increased the maximum tolerated dose of IL-13 cytotoxin by 2 -fold, the anti-tumor therapeutic activity of IL- 13 cytotoxin improved in both gender of animals.

A $50 \mu \mathrm{g} / \mathrm{kg} / \mathrm{day}$ or $75 \mu \mathrm{g} / \mathrm{kg} /$ day dose of IL-13 cytotoxin given by IV and CI did not show any toxicities in KCCT873 tumor xenografted nude mice. Although CI treated mice showed slight superiority in anti-tumor activity, significant differences in the anti-tumor activity were not observed. HN12 xenografts treated with $150 \mu \mathrm{g} / \mathrm{kg} /$ day IV for 7 days had highly elevated levels of hepatic transaminases and potassium, suggesting liver toxicity. Although $300 \mu \mathrm{g} / \mathrm{kg} /$ day CI treated mice also showed elevated levels of these parameters, the intensity of increase was lower than in the $150 \mu \mathrm{g} / \mathrm{kg} /$ day IV treated mice. Histologic examinations suggested that all four vital organs-liver, kidney, lung, and spleenwere severely affected by $150 \mu \mathrm{g} / \mathrm{kg} /$ day IV treatment with IL-13 cytotoxin. On the other hand, organs from $300 \mu \mathrm{g} / \mathrm{kg} /$ day CI treatment group showed less severe toxicities compared with $150 \mu \mathrm{g} / \mathrm{kg} /$ day IV treated mice.

Several approaches have been tested to improve the anti-tumor activity of cytotoxins and immunotoxins and to decrease toxicity and immunogenicity of these agents. Among these approaches, site-specific PEGylation of molecule and insertion of nucleotide sequences of human immunoglobulin genes into the gene encoding mouse monoclonal antibodies have been successfully shown to prevent inadequate recruitment of host leukocytes bearing constant $(\mathrm{Fc})$ region receptors $(34,36,39,40)$. These approaches resulted into prolonged half-life of the circulating drug. In our current study, we utilized a device for CI of drug as an alternate approach to increase the availability of drug. This approach resulted in improved anti-tumor effect and decreased toxic effects. When implanted, interstitial fluid enters the CI pump via the semipermeable membrane because of the osmotic difference between the fluid and the salt solution in the pump. The fluid causes expansion of the salt layer, which compresses the flexible drug reservoir and forces solution out of the delivery portal (41). Utilizing this device, IL-13 cytotoxin can be continuously administrated systemically in body.

In summary, through CI, we successfully decreased the toxicities and increased the efficacy of IL-13 cytotoxin in tumor-bearing hosts. Because IP and IV administration of IL-13 cytotoxin has been shown to have a significant anti-tumor activity in IL-13R expressing tumors $(10,16,33)$, its efficacy can be further enhanced by CI. We have begun Phase I/II clinical trials in patients with recurrent glioblastoma and progressive renal cell carcinoma (42). Based on our current results, we may be able to develop next generation clinical studies utilizing CI. Because IV bolus administration produces transient peak levels of drug, CI may provide constant high levels of drug exposure to tumors to enhance its systemic effectiveness.

\section{Acknowledgments}

We thank Ms. Pamela Dover for the procurement of reagents and technical assistance, and Dr Bharat H. Joshi for providing recombinant IL13-PE38QQR. We also thank Drs Raymond P. Donnelly and David Essayan of CBER/FDA for reading this manuscript. These studies were conducted as part of a collaboration between the FDA and NeoPharm Inc. under a Cooperative Research and Development Agreement (CRADA).

\section{References}

1. Drixler TA, Borel Rinkes IHM, Ritchie ED, van Vroonhoven TJMV, Gebbink MFBG, Voest EE. (2000) Continuous administration of angiostatin inhibits accelerated growth of colorectal liver metastases after partial hepatectomy. Cancer Res. 60: 1761-1765.

2. Cohen-Jonathan E, Muschel RJ, McKenna WG, et al. (2000) Farnesyltransferase inhibitors potentiate the antitumor effect of radiation on a human tumor xenograft expressing activated HRAS. Radiat. Res. 154: 125-132.

3. Tejeda M, Gaal D, Schwab RE, Pap A, Szuts T, Keri GY. (2000) Influence of various administration routes on the antitumor efficacy of TT-232, a novel somatostatin analog. Anticancer Res. 20: 1023-1028.

4. Thomas-Vaslin V, Bellier B, Cohen JL, et al. (2000) Prolonged allograft survival through conditional and specific ablation of alloreactive $\mathrm{T}$ cells expressing a suicide gene. Transplantation 69: 2154-2161.

5. Minty A, Chalon P, Derocq JM, et al. (1993) Interleukin-13 is a new human lymphokine regulating inflammatory and immune responses. Nature (Lond) 36: 248-251.

6. Kapp U, Yeh WC, Patterson B, et al. (1999) Interleukin 13 is secreted by and stimulates the growth of Hodgkin and ReedSternberg cells. J. Exp. Med. 189: 1939-1946.

7. Obiri NI, Debinski W, Leonard WJ, Puri RK. (1995) Receptor for interleukin 13: Interaction with interleukin 4 by a mechanism that does not involve the common $\gamma$ chain shared by receptors for interleukins 2, 4, 7, 9, and 15. J. Biol. Chem. 270: 8797-8804.

8. Puri RK, Leland P, Obiri NI, et al. (1996) Targeting of interleukin-13 receptor on human renal cell carcinoma cells by a recombinant chimeric protein composed of interleukin-13 and a truncated form of Pseudomonas exotoxin A (PE38QQR). Blood 87: 4333-4339.

9. Husain SR, Obiri NI, Gill P, et al. (1997) Receptor for interleukin-13 on AIDS-associated Kaposi's sarcoma cells served as a new target for a potent Pseudomonas exotoxin-based chimeric toxin protein. Clin. Cancer Res. 3: 151-156.

10. Husain SR, Puri RK. (2000) Interleukin-13 fusion cytotoxin as a potent targeted agent for AIDS-Kaposi's sarcoma xenograft. Blood 95: 3506-3513.

11. Joshi BH, Plautz GE, Puri RK. (2000) IL-13 receptor $\alpha$ chain: a novel tumor associated transmembrane protein in primary explants of human malignant gliomas. Cancer Res. 60: 1168-1172. 
12. Kawakami M, Leland P, Kawakami K, Puri RK. (2001) Mutation and functional analysis of IL- 13 receptors in human malignant glioma cells. Oncol. Res. 12: 459-467.

13. Maini A, Hillman G, Haas GP, et al. (1997) Interleukin-13 receptors on human prostate carcinoma cell lines represent a novel target for a chimeric protein composed of IL-13 and a mutated form of Pseudomonas exotoxin. J. Urol. 158: 948-953.

14. Murata T, Obiri NI, Debinski W, Puri RK. (1997) Human ovarian carcinoma cell lines express IL- 4 and IL- 13 receptors: comparison between IL-4- and IL-13-induced signal transduction. Int. J. Cancer 70: 230-240.

15. Kawakami M, Kawakami K, Puri RK. (2002) Apoptotic pathways of cell death induced by an interleukin- 13 receptortargeted recombinant cytotoxin in head and neck cancer cells. Cancer Immunol. Immunother. 50: 691-700.

16. Kawakami K, Kawakami M, Joshi BH, Puri RK. (2001) Interleukin- 13 receptor-targeted cancer therapy in an immunodeficient animal model of human head and neck cancer. Cancer Res. 61: 6194-6200.

17. Joshi BH, Kawakami K, Leland P, Puri RK. (2002) Heterogeneity of interleukin-13 receptor expression and subunit structure in squamous cell carcinoma of head and neck: differential sensitivity to a chimeric fusion protein comprised of interleukin-13 and a mutated form of Pseudomonas exotoxin. Clin. Cancer Res. 8: 1948-1956.

18. Murata T, Noguchi PD, Puri RK. (1996) IL-13 induces phosphorylation and activation of JAK2 Janus Kinase in human colon carcinoma cell lines: similarities between IL-4 and IL13 signaling. J. Immunol. 156: 2972-2978.

19. Obiri NI, Leland P, Murata T, Debinski W, Puri RK. (1997) The IL-13 receptor structure differs on various cell types and may share more than one component with IL-4 receptor. J. Immunol. 158: 756-764.

20. Murata T, Obiri NI, Puri RK. (1998) Structure of and signal transduction through interleukin-4 and interleukin-13 receptors. Int. J. Mol. Med. 1: 551-557.

21. Murata T, Husain SR, Mohri H, Puri RK. (1998) Two different IL-13 receptor chains are expressed in normal human skin fibroblasts, and IL-4 and IL-13 mediate signal transduction through a common pathway. Int. Immunol. 10: 1103-1110.

22 Hilton DJ, Zhang JG, Metcalf D, Alexander WS, Nicola N, Willson TA. (1996) Cloning and characterization of a binding subunit of the interleukin-13 receptor that is a component of the interleukin-4 receptor. Proc. Natl. Acad. Sci. U.S.A. 3: $497-501$.

23. Aman MJ, Tayebi N, Obiri NI, Puri RK, Modi WS, Leonard WJ. (1996) cDNA cloning and characterization of the human interleukin 13 receptor $\alpha$ chain. J. Biol. Chem. 271: 29265- 29270.

24. Miloux B, Laurent P, Bonnin O, et al. (1997) Cloning of the human IL-13R $\alpha 1$ chain and reconstitution with the IL-4R $\alpha$ of a functional IL-4/IL-13 receptor complex. FEBS Lett. 401: 163-166.

25. Obiri NI, Murata T, Debinski W, Puri RK. (1997) Modulation of interleukin (IL)-13 binding and signaling by the $\gamma_{\mathrm{c}}$ chain of the IL-2 receptor. J. Biol. Chem. 272: 20251-20258.

26. Caput D, Laurent P, Kaghad M, et al. (1996) Cloning and characterization of a specific interleukin (IL)-13 binding protein structurally related to the IL-5 receptor $\alpha$ chain. J. Biol. Chem. 271: 16921-16926.

27. Donaldson DD, Whitters MJ, Fitz LJ, et al. (1998) The murine IL-13 receptor $\alpha 2$ : molecular cloning, characterization, and comparison with murine IL-13 receptor $\alpha$ l. J. Immunol. 161: 2317-2324.

28. Kawakami K, Taguchi J, Murata T, Puri RK. (2001) The Interleukin-13 receptor $\alpha 2$ chain: an essential component for binding and internalization but not for IL-13 induced signal transduction through the STAT6 pathway. Blood 276: 2673-2679.

29. Kawakami K, Takeshita F, Puri RK. (2001) Identification of distinct roles for a dileucine and a tyrosine internalization motif in the interleukin-13 binding component IL-13 receptor $\alpha 2$ chain. J. Biol. Chem. 276: 25114-25120.

30. Debinski W, Obiri NI, Pastan I, Puri RK. (1995) A novel chimeric protein composed of interleukin 13 and Pseudomonas exotoxin is highly cytotoxic to human carcinoma cells expressing receptors for interleukin 13 and interleukin 4. J. Biol. Chem. 270: 16775-16780.

31. Kawakami K, Joshi BH, Puri RK. (2000) Sensitization of cancer cells to interleukin 13-Pseudomonas exotoxin-induced cell death by gene transfer of interleukin 13 receptor $\alpha$ chain. Hum. Gene Ther. 11: 1829-1835.

32. Kawakami K, Husain SR, Bright RK, Puri RK. (2001) Gene transfer of interleukin 13 receptor $\alpha 2$ chain dramatically enhances the antitumor effect of IL- 13 receptor-targeted cytotoxin in human prostate cancer xenografts. Cancer Gene Ther. 8: $861-868$.

33. Husain SR, Joshi BH, Puri RK. (2001) Interleukin-13 receptor as a unique target for anti-glioblastoma therapy. Int. J. Cancer 92: 168-175.

34. Frankel, AE, Kreitman RJ, Sausville EA. (2000) Targeted toxins. Clin. Cancer Res. 6: 326-334.

35. Kreitman RJ, Wilson WH, White JD, et al. (2000) Phase I trial of recombinant immunotoxin Anti-Tac(Fv)-PE38 (LMB-2) in patients with hematologic malignancies. J. Clin. Oncol. 18: $1622-1636$.

36. Kreitman RJ, Margulies I, Stetler-Stevenson M, Wang QC, FitzGerald DJP, Pastan I. (2000) Cytotoxic activity of disulfide-stabilized recombinant immunotoxin RFB4(dsFv)PE38 (BL22) toward fresh malignant cells from patients with B-cell leukemias. Clin. Cancer Res. 6: 1476-1487.

37. Cardinali M, Pietraszkiewicz H, Ensley JF, Robbins KC. (1995) Tyrosine phosphorylation as a marker for aberrantly regulated growth-promoting pathways in cell lines derived from head and neck malignancies. Int. J. Cancer 61: 98-103.

38. Kawakami K, Leland P, Puri RK. (2000) Structure, function, and targeting of interleukin 4 receptors on human head and neck cancer cells. Cancer Res. 60: 2981-2987.

39. Tsutsumi Y, Onda M, Nagata S, Lee B, Kreitman RJ, Pastan I. (2000) Site-specific chemical modification with polyethylene glycol of recombinant immunotoxin anti-Tac(Fv)-PE38 (LMB-2) improves antitumor activity and reduces animal toxicity and immunogenicity. Proc. Natl. Acad. Sci. U.S.A. 97: 8548-8553.

40. Onda M, Olafsen T, Tsutsumi Y, Bruland OS, Pastan I. (2001) Cytotoxicity of antiosteosarcoma recombinant immunotoxins composed of TP-3 Fv fragments and a truncated Pseudomonas exotoxin A. J. Immonother. 24: 144-150.

41. Durect Corporation. (2000) Technical information manual, ALZET osmotic pumps. pp 1, Palo Alto.

42. Prados M, Lang F, Strauss L, et al. (2001) Pre- and postresection interstitial infusions of IL13-PE38QQR cytotoxin: phase I study in recurrent respectable malignant glioma. World Federation of Neuro-Oncology First Quadrennial Meeting, Washington D.C. 